\title{
TOŻSAMOŚĆ LOKALNA W PRZEMYSŁOWYCH REGIONACH UKRAINY: DONIECK I DNIEPROPIETROWSK ZARYS PROBLEMATYKI
}

W efekcie trwających od 150 lat procesów industrializacyjnych obwody doniecki i dniepropietrowski należą do najważniejszych okręgów przemysłowych Ukrainy. W niniejszym artykule staram się nakreślić, w jaki sposób charakter tych regionów wpływa na kształt dyskursu tożsamościowego ich mieszkańców. Powyższy problem ma jedynie niewielką literaturę przedmiotu, dotycząca przede wszystkim Donbasu. Tożsamości regionalnej obwodu dniepropietrowskiego poświęcono zaledwie kilka publikacji, które można by - jakkolwiek z trudem - uznać za naukowe. Na ich tle wyróżniają się: publiczny wykład (styczeń 2012) historyka Andrija Portnowa Дніпропетровськ. Як оповісти історію мiста без історії [Dniepropietrowsk. Jak opowiedzieć historię miasta bez historii] ${ }^{1}$ oraz praca Sergija Żuka Rock and Roll in the Rocket City: The West, Identity, and Ideology in Soviet Dniepropetrovsk, 1960-1985 [Rock and roll w rakietowym mieście. Zachód, tożsamość i ideologia w radzieckim Dniepropietrowsku, 1960-1985] (2010), który koncentruje się na tożsamości młodych mieszkańców miasta w ostatnich 25 latach istnienia ZSRR ${ }^{2}$. Ponadto w literaturze naukowej znajdują się wzmianki dotyczące lokalnej tożsamości, zwłaszcza w kontekście analizy fenomenu znanego jako „klan dniepropietrowski”, ale maja one raczej charakter dygresji niż systematycznej analizy zjawiska.

W porównaniu z autoidentyfikacja dniepropietrowska, autoidentyfikacja doniecka przyciagała więcej uwagi naukowców, nie tylko

${ }^{1}$ П. Солодько (P. Sołodko), Дніпропетровськ. Як оповісти історію міста без історії (конспект лекиї A. Портнова) [konspekt wykładów A. Portnowa], «Історична правда» [Historyczna Prawda], 26 I 2012.

${ }^{2} \mathrm{~S}$. Zhuk, Rock and Roll in the Rocket City: The West, Identity, and Ideology in Soviet Dniepropetrovsk, 1960-1985, Baltimore, M.D. - Washington, DC 2010. 
ukraińskich. Należy wyróżnić prace amerykańskiego badacza japońskiego pochodzenia Hiroaki Kuromiyi, Freedom and Terror in the Donbas: A Ukrainian-Russian Borderland, 1870s-1990s [Wolność i terror w Donbasie. Ukraińsko-rosyjska granica od lat 70. XIX w. do lat 90. XX w. $]^{3}$, oraz niemieckiej badaczki Kerstin Zimmer, Machteliten im ukrainischen Donbass. Bedingungen und Konsequenzen der Transformation einer alten Industrieregion [Elity władzy w ukraińskim Donbasie. Warunki i skutki transformacji starego przemysłowego regionu] $]^{4}$. Interesującym opracowaniem - powstałym w oparciu o metodologię oral history - jest ksiażka Workers of the Donbass Speak: Survival and Identity in the New Ukraine, 1989-1992 [Pracownicy Donbasu mówia. Przetrwanie i tożsamość w nowej Ukrainie, 1989-1992] ${ }^{5}$. Do dziś nie powstała natomiast ani jedna ukraińska monografia poświęcona zagadnieniu tożsamości donieckiej. Jej brak tylko częściowo kompensowany jest niewielką liczbą artykułów naukowych. Wypada podkreślić zainteresowanie problemem tożsamości donieckiej i dniepropietrowskiej ze strony tzw. wolnych socjologów ${ }^{6}$. Przeprowadzili oni badania porównawcze tożsamości różnych regionów Ukrainy ${ }^{7}$, których wyniki stały się przedmiotem dyskusji krajowych i międzynarodowych ${ }^{8}$.

Na marginesie należy wspomnieć, że wzrost społecznego zainteresowania problematyka tożsamości w warunkach braku literatury naukowej przyczynił się do rozwoju quasi-naukowego mitotwórstwa, którego przykładami są: książka politologa, kierownika ukraińskiego oddziału Instytutu Krajów Wspólnoty Niepodległych Państw w Moskwie, Włodzimierza Korniłowa Донецко-Криворожская

${ }^{3}$ H. Kuromiya, Freedom and Terror in the Donbas: A Ukrainian-Russian Borderland, 1870s-1990s, Cambridge 1998.

${ }^{4}$ K. Zimmer, Machteliten im ukrainischen Donbass. Bedingungen und Konsequenzen der Transformation einer alten Industrieregion, Berlin 2006.

${ }^{5}$ L. Siegelbaum, D. Walkowitz, Workers of the Donbass Speak: Survival and Identity in the New Ukraine, 1989-1992, New York 1995.

${ }^{6}$ Zob. A. Задоя (A. Zadoja), Ценностные ориентиры как основа стратегического планирования развития территорий [Systemy wartości jako podstawa strategicznego planowania i rozwoju miasta], «Академічний огляд» [Przegląd Akademicki] 2010, nr 2, s. 5-14.

${ }^{7}$ Zob. «Львів-Донецьк: соціологічний аналіз групових ідентичностей та іерархій соціальних лояльностей 1994, 1999, 2004 pp» [Lwów-Donieck: socjologiczna analiza tożsamości zbiorowej i hierarchii więzi społecznych w latach 1994, 1999, 2004], «Україна модерна» [Nowoczesna Ukraina] 12(2): «Львів - Донецьк: соціяльні ідентичності в сучасній Україні». Спеціяльний випуск [Lwów - Donieck: identyfikacje społeczne we współczesnej Ukrainie], wyd. specjalne, Київ - Львів 2007, s. 299-356.

${ }^{8}$ Tamże, s. 7-26. 
республика: Расстрелянная мечта [Doniecko-krzyworoska republika. Rozstrzelane marzenie] ${ }^{9}$ oraz zbiór materiałów i artykułów Проблель региональной идентичности Донбасса [Problematyka regionalnej tożsamości Donbasu $]^{10}$. Publikacje te, podszywając się pod dyskurs naukowy, zniekształcają fakty, a służą tworzeniu teoretycznej podbudowy dla idei politycznej izolacji Donbasu.

W niniejszym tekście jako narzędzie analityczne wykorzystujemy pojęcia: „tożsamości lokalnej” - na określenie utożsamiania się z miejscem zamieszkiwania (miasto lub inna jednostka administracyjna) - i „tożsamości regionalnej” - na określenie utożsamiania się z szerszym obszarem geograficznym, wyznaczonym przez granice administracyjne (np. Donbas). Tożsamość regionalna, podobnie jak narodowa, ma charakter ideologiczny, może być płaszczyzną rywalizacji $\mathrm{z}$ osobami i zbiorowościami identyfikującymi się z innymi regionami (narodami). Natomiast tożsamość lokalna ma charakter „ojczyzny prywatnej”, odzwierciedla standardowe, „paszportowe”, przywiazanie do miejsca zamieszkiwania.

\section{Charakterystyka ogólna}

Kształtowanie tożsamości terytorialnej omawianych obwodów było ściśle powiązane z procesami demograficznymi. W drugiej połowie XIX i w XX w. region dniepropietrowski i Donbas przyjęły trzy fale migracyjne. Pierwsza była uwarunkowana industrializacja z ostatnich dziesięcioleci XIX w.: 61,5\% nowych fabryk i zakładów w ukraińskich guberniach Imperium Rosyjskiego zbudowano na terenie guberni katerynosławskiej (obejmującej obszar dniepropietrowski i większość Donbasu $)^{11}$. Druga fala przypadała na czas odbudowy po wojnie domowej i na okres radzieckiej industrializacji. Trzecia - po II wojnie światowej. Przy czym jeśli w regionie donieckim pierwszy etap zasiedlenia odbywał się na prawie surowym korzeniu, to w dniepropietrowskim - dzięki

${ }^{9}$ В. Корнилов (W. Korniłow), Донецко-Криворожская республика: Расстрелянная мечта [Doniecko-krzyworoska republika. Rozstrzelane marzenie], Харьков 2011.

${ }^{10}$ А. Иванов (A. Iwanow), А. Мартынов (A. Martynow), Проблемы региональной идентичности Донбасса: сборник аналитических статей [Problematyka regionalnej tożsamości Donbasu. Biblioteka artykułów analitycznych], Донецк 2011.

${ }^{11}$ I. Гуржій (I. Gurżij), Украӥна в систелі всеросійського ринку 60-90-х років $X I X \mathrm{~cm}$ [Ukraina w systemie rynku ogólnorosyjskiego latach 60.-90. XIX w.], Kyjiv 1968, s. 25. 
miejskiej kulturze Katerynosławia - proces kształtowania tożsamości był bardziej ukierunkowany, uporządkowany. Pojawiające się nowe elementy nakładały się na już istniejąca tożsamość lokalna, co pozwoliło zachować pewną ciagłość miejscowych tradycji. Natomiast podwaliny tożsamości donieckiej powstały dopiero w latach 30. XX w., w dobie radzieckiej modernizacji.

W przypadku obu regionów właściwy proces kształtowania tożsamości regionalnej rozpoczął się w latach 60. i 70. XX w., po ustabilizowaniu sytuacji demograficznej. W latach 90. tożsamość regionalna okazała się na tyle silna, że zaczęli ją dostrzegać także obserwatorzy zewnętrzni.

Autor w swoich badaniach skoncentrował się na terytorium współczesnych obwodów: donieckiego i dniepropietrowskiego, w razie potrzeby odwołując się do porównań z regionami sąsiednimi. Opracowanie każdego z obwodów zawiera prezentacje następujących kwestii:

- podstawowej ideologicznej sprzeczności leżącej u podstaw tożsamości obu omawianych terenów;

- dynamiki miejscowych elit;

- przestrzennego wymiaru tożsamości;

- tożsamości społeczno-ekonomicznej;

- tożsamości politycznej i stosunku do Ukrainy;

- krajowej (regionalnej) i kulturowej tożsamości.

\section{Tożsamość doniecka}

\section{Podstawowa sprzeczność ideologiczna}

Regionalną tożsamość doniecka cechuje występowanie napięcia związanego z oddziaływaniem dwóch sprzecznych punktów odniesienia, organizujących dyskurs tożsamościowy: „stepowej wolności” i galernickiego wysiłku, wręcz niewolniczej pracy. Jak lapidarnie ują to Kuromiya: „Przez cały czas swego istnienia Donbas był wcieleniem wolności, która właśnie wyznaczyła brutalną i okrutna polityczną historię Donbasu. [...] Zafascynowany wolnością oraz możliwościami tego przygranicznego regionu, osiadał tu pstry lud z całego kraju i zagranicy, a bezlitosna ekonomiczna eksploatacja i starcia etniczne były częścią życia codziennego w Donbasie"12.

Sytuację w zagłębiu w okresie gospodarczego boomu w ostatnim trzydziestoleciu XIX w. i na początku XX w. można porównać z sytuacja

\footnotetext{
${ }^{12}$ H. Kuromiya, dz. cyt., s. 18.
} 
Dzikiego Zachodu z epoki kolonizacji Ameryki. Wielkim czynom, heroizmowi, możliwościom kariery towarzyszyły gwałt i bezprawie. Z tym jednak, że bohaterem heroicznych dokonań był w tym przypadku radziecki proletariusz.

\section{Dynamika miejscowych elit}

Elity Donbasu formowały się głównie w ramach sektora przemysłowego. Na pierwszym etapie industrializacji regionu można było obserwować radykalne przeciwstawienie proletariatu i kadry administracyjnej - „białych kołnierzyków” i „niebieskich kołnierzyków”. Jeszcze bardziej ostry był podział na pracowników najemnych oraz właścicieli przedsiębiorstw przemysłowych. Przedsiębiorcy byli główną władzą w regionie. Np. przedsiębiorstwo Noworosyjska Spółka, z siedziba w Juziwce, była monopolistycznym właścicielem osady, wszystkich gruntów i nieruchomości. Z tego tytułu należało do niej m.in. prawo wydawania pozwoleń na działalność komercyjna. Chroniąc swą monopolistyczną pozycję, spółka blokowała przy tym do 1917 r. nadanie osadzie statusu miasta.

Po wojnie domowej bariery rozdzielające grupy społeczne i zawodowe zanikały, zmniejszał się dystans pomiędzy przełożonymi i pracownikami. Według relacji naocznych świadków dyrektorzy kopalni dość dobrze dbali o wszystkie szczegóły życia swych pracowników, próbując pomóc im i ich rodzinom, jednocześnie wymagając bezwarunkowej lojalności i posłuszeństwa. Podobny model relacji funkcjonował po II wojnie światowej.

Taki układ stosunków przyczyniał się do wzmacniania poczucia własnej wartości u pracowników, którzy nie bali się walczyć o swoje interesy. Według świadków w czasach sowieckich górnicy, którzy uznawali, że ich wynagrodzenie było zbyt małe w stosunku do wykonywanej pracy, potrafili demonstrować oburzenie, rzucając swą pensję na biurko dyrektorowi kopalni. Region doniecki był w drugiej połowie lat 80. i na początku 90. XX w. centrum ruchu strajkowego na Ukrainie.

Należy bardzo mocno podkreślić, że występowanie - niekiedy nawet ostrych - konfliktów między różnymi grupami społecznymi a zawodowymi nie koliduje $\mathrm{z}$ silnym poczuciem zasadniczej wspólnoty interesów i silnego poczucia odrębności regionalnej wszystkich mieszkańców Donbasu.

W połowie lat 90. elity Donbasu stanęły w obliczu ryzyka utraty dotychczasowego znaczenia. Pojawiło się niebezpieczeństwo odsunięcia na drugi plan przez elity dniepropietrowskie. Zostało ono jednak 
zażegnane, a elity donieckie nie tylko odzyskały pozycję miejscowa, ale też zaczęły na początku XXI stulecia zwiększać swoje wpływy na poziomie elit ogólnopaństwowych.

Ciekawym zjawiskiem z ostatnich kilkunastu lat jest próba objęcia nazwa „Donbasu” obszarów sasiadujących z obwodem donieckim - Mariupola oraz Ługańska. Należy przy tym zaznaczyć, że zwłaszcza inteligencja ługańska mocno dystansuje się od związków z Donbasem. Jak ocenia regionalista Igor Sajenko: „Każdy mieszkaniec tego [ługańskiego] regionu na pytanie o położenie Donbasu bez wahania wskaże na południe, wyraźnie lokując go poza swoją miejscowością. Nie ulega wątpliwości, że większość mieszkańców obwodu ługańskiego nie poczuwa się do więzi z Donbasem. Co więcej, bezpodstawne jest zaliczanie do Donbasu północnej części obwodu donieckiego"13.

Sajenko uzasadnia swoje stanowisko faktem, że w Ługańsku nie występuje bardzo znacząca dla tożsamości donieckiej kultura górnicza: „Prawdopodobieństwo spotkania w Ługańsku górnika jest mniej więcej takie, jak marynarza w Kijowie”. Nie kwestionując trafności jego uwag, można jednak postawić pytanie, czy nie mamy tu do czynienia ze współistnieniem ługańskiej tożsamości lokalnej z doniecką (czy donbaska) tożsamością regionalną.

\section{Przestrzenny wymiar tożsamości}

O ile doniecki step jest podstawowym toposem folkloru regionalnego, o tyle najważniejszym składnikiem donieckiej tożsamości regionalnej jest krajobraz stworzony rękami człowieka: „Wiele ukraińskich miast, nawet tak dużych jak Donieck, Makiejewka, Gorliwka, zachowuje historycznie ukształtowany «wiejski» charakter, ponieważ miasta te powstały z połączenia osad przemysłowych tworzonych w pobliżu kopalni, zakładów koksochemicznych, metalurgicznych etc. Dopiero w kolejnych latach rozwijała się tam klasyczna tkanka wielkomiejska. Urbanizacja była więc $\mathrm{w}$ tym przypadku niejako ubocznym efektem rewolucji technicznej oraz industrializacji, a nie odrębnym procesem społeczno-gospodarczym"14.

Pod koniec XIX i na początku XX w. symbolem Doniecka był pejzaż przemysłowy. Ciekawy przykład stanowi wykorzystanie pejzaży

${ }^{13}$ I. Caєнко (I. Sajenko), Донбас і Луганщина -дві великі різниці [Donbas i obwód Łużański - dwie różnice], «Історична правда» z 29 VIII 2012.

${ }^{14}$ B. Амитан (V. Amitan) i in., Социально-эконолическое развитие городов пролышленного региона [Społeczno-gospodarczy rozwój miast regionu przemysłowego], Донецк 2002, s. 41. 
fabrycznych jako tła w plakatach propagandowych z okresu wojny domowej, m.in. zachęcających do obrony regionu w obliczu ofensywy polskiej 1920 r. W następnych dziesięcioleciach jednym z kluczowych elementów symboliki krajobrazu donieckiego stała się kopalnia.

W latach 60. i 70. rozpoczął się okres, w którym starano się pokazać Donieck jako miasto nie tylko przemysłu, ale też dbałości o środowisko naturalne i estetykę życia codziennego. Jednym z symboli obwodu stała się wówczas ,palma Mercałowa” ${ }^{15}$. Na te dekady przypadają również próby zadbania o wygląd zewnętrzny miasta: świadkowie wspominaja względną czystość na ulicach i działające wieczorem oświetlenie. Ponadto władze lokalne zainicjowały kampanię sadzenia kwiatów, czemu towarzyszyło promowanie Doniecka jako „miasta róż” (w Ługańsku z kolei ulice ozdabiały fontanny, stąd otrzymał on przydomek „miasta fontann”).

\section{Społeczno-ekonomiczny wymiar tożsamości}

Podstawą tożsamości regionalnej jest zawód górnika, choć równolegle rozwijało się hutnictwo i przemysł maszynowy. Symbole górnictwa towarzyszą całej historii regionu - niezmiennie od czasów radzieckich pozostając $\mathrm{w}$ godle miasta. W granicach obwodu donieckiego znajduje się 51 miast, w których wydobywa się lub przerabia węgiel. W 42 z nich w przemysł węglowy zatrudnia połowę pracowników przemysłowych ${ }^{16}$.

Ze względu na znaczenie dla ZSRR przemysłu węglowego, Donbas był miejscem sporych nakładów inwestycyjnych, cieszył się najlepszym zaopatrzeniem w produkty żywnościowe i dobra konsumpcyjne. Ługański politolog Jurij Jurow podkreślał: „Donbas oficjalnie był uważany za kraj uprzywilejowany, witrynę socjalizmu, ogólnozwiązkową kotłownię. Był dobrze zaopatrzony w tanią wódkę, kiełbasę i inne symbole socjalistycznego raju. Tu szybko przesuwała się kolejka po mieszkania, nie brakowało pracy - to wszystko przyciaggało głodny miejski i wiejski proletariat z innych regionów ZSRR"17.

Nawiasem mówiąc, zaraz po wojnie domowej miały miejsce próby mobilizacji siły roboczej. Na przykład w lutym 1920 r., gdy Donbas został proklamowany jednostką gospodarczą i administracyjno-

${ }^{15}$ Wizerunek palmy wykuty w 1896 r. z jednego kawałka stali na wystawę światową w Paryżu w 1896 r. Palma stała się w 1999 r. oficjalnym herbem obwodu donieckiego.

${ }^{16}$ B. Амитан (V. Amitan) i in., dz. cyt., s. 79.

${ }^{17}$ Ю. Юров (Ј. Jurow), Кримська карта в донбаськолу пасьянсі [Krymska karta w donbaskim pasjansie], w: Генеза. Філософбія. Iсторія. Політологія [Geneza. Filozofia. Historia. Politologia], Kyjiv 1995, s. 189. 
-wojskowa, zaprowadzono obowiązek pracy dla ludności męskiej, w każdym z 16 górniczych rejonów została stworzona komendantura, podporządkowana sztabowi regionalnemu ${ }^{18}$. Ale inicjatywa nie powiodła się - po prostu, ludzie nie chcieli pracować tylko za jedzenie. Warto zauważyć, że w okresie powojennym, kiedy dokonywano odbudowy Donbasu, która rząd uznał za jeden z priorytetów (wprowadzono nawet medal „Za odrodzenie Donbasu"), stosowano nieco bardziej elastyczne podejście. Według respondentów choć do pracy w kopalniach przymusowo wcielano chłopów z centralnych regionów Ukrainy i poddawano ich dyscyplinie wojskowej, wypłacano im dość wysokie wynagrodzenie. Ucieczki z miejsca pracy były jednak nadal bardzo częste.

W latach 60., a jeszcze bardziej w 70. zachęty ekonomiczne sprawiały, że region był bardzo atrakcyjny dla pracowników. Do gwałtownego pogorszenia sytuacji doszło w latach 90. Po zamknięciu części kopalni ludność masowo opuszczała region, nierzadkim widokiem były puste wieżowce. Jednocześnie powstał problem kryminalizacji: jakkolwiek istniał on i w innych regionach Ukrainy, to właśnie Donieck stał się symbolem przestępczości lat 90 . Warto przy tym zwrócić uwagę na pewien paradoks: choć w obwodzie donieckim ogólny poziom produkcji przemysłowej w r. 2000 wynosił zaledwie $54,5 \%$ poziomu z r. 1990 , to zatrudnienie w przemyśle wzrosło w ciagu dekady o $7,1 \%{ }^{19}$. Wydaje się, że wśród wielu czynników jednym z najważniejszych był wpływ paternalistycznego modelu stosunków: zatrudnienie było podtrzymywane sztucznie po to, by względnie efektywna ekonomicznie branża gospodarki zapewniała minimalny poziom stabilizacji materialnej ludności.

Z początkiem XXI stulecia „nowym bohaterem” donieckiej tożsamości staje się biznesmen, zwłaszcza z branży hutniczej. To bowiem hutnictwo po serii przemian gospodarczych stało się najważniejszą branżą gospodarki regionu.

Rozpatrując rzecz w kategoriach semiotycznych, dość znamienny jest pozostawienie bez większych zmian herbu Doniecka po 1991 r. Podkreśla to miejscowe zapotrzebowanie na poczucie pewności w życiu oraz adekwatności „donieckich tradycyjnych wartości” do nowych warunków ekonomicznych i politycznych (il. 1).

${ }^{18}$ C. Кульчицький [S. Kulczycki], Колунізл в Україні: перше десятиріччя (1919-1928) [Komunizm na Ukrainie: pierwsze dziesięciolecie (1919-1928)], Kyjiv, 1996, s. 101.

${ }^{19}$ B. Амитан (V. Amitan) i in., dz. cyt., s. 101-104. 

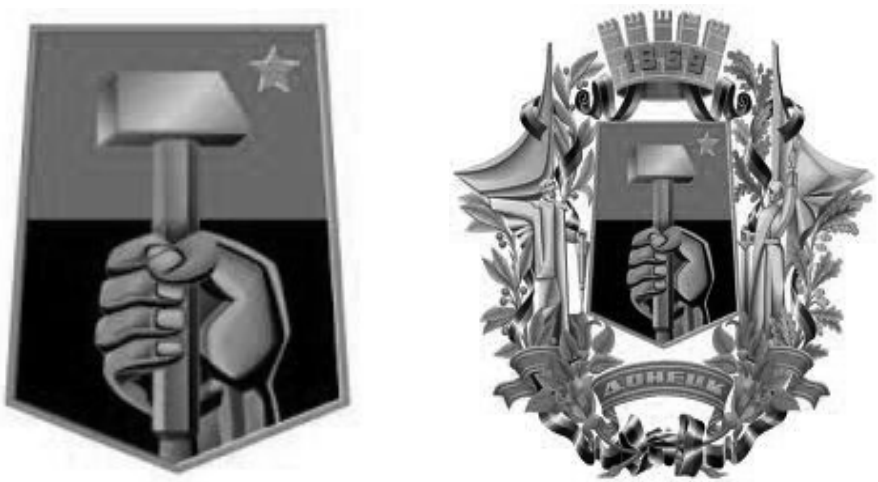

Il. 1. Herby Doniecka: herb z okresu radzieckiego oraz herb współczesny

\section{Tożsamość polityczna i stosunek do Ukrainy}

Badania socjologiczne wskazują na bardzo istotną rolę tożsamości lokalnej w dyskursie tożsamościowym mieszkańców Ukrainy. Jednocześnie materiały badawcze dotyczące Doniecka dowodza, że region ten $\mathrm{w}$ niewielkim stopniu jest identyfikowany z Ukraina.

Zarówno w okresie międzywojennym, jak i obecnie notuje się wypowiedzi o kimś, kto pojechał do Dniepropietrowska - że „pojechał na Ukrainę". Towarzyszyło temu w czasach radzieckich rozpoznawanie odrębności Ukraińskiej Republiki Radzieckiej jako odrębnego bytu politycznego, a Kijowa jako miasta stołecznego (Ukrainy) ${ }^{20}$. W latach 90. doszło do znacznego wzmocnienia tożsamości regionalnej (donieckiej), która, zdaniem niektórych badaczy, wypełniła pustkę powstałą po zniknięciu „swojego” państwa - ZSRR ${ }^{21}$.

Wielu autorów wskazuje także, że rozwój donieckiej tożsamości regionalnej nie oznacza rozwoju izolacjonizmu czy autonomizacji. Inaczej niż na Krymie, w obwodzie donieckim rozwijają się ruchy społeczne, których członkowie deklarują wolę przyłączenia się do Rosji lub odbudowy ZSRR - największe jednak znaczenie ma ruch na rzecz poprawy pozycji regionu w ramach Ukrainy: „Elita władzy Donbasu pragnie nie autonomii, ale ogólnoukraińskiej władzy[...] Poza tym

${ }^{20}$ Б. Бахтеєв [В. Bachtieew], А Украӥни все ж таки дві... [Ukrainy jednak dwie...], «Сучасність» [Współczesność] 2004, nr 10, s. 95.

${ }^{21} \Gamma$. Коржов (G. Korżow), Региональная идентичность Донбасса: генезис и тендениии развития в условиях общественной трансфборлации [Regionalna tożsamość Donbasu. Geneza i kierunki rozwoju w warunkach transformacji społecznej, «Социология: теория, методы, маркетинг» [Socjologia: Teoria, Metody, Marketing] 2006, nr 4, s. 40. 
«tłuste koty» Donbasu [oligarchia finansowo-polityczna rekrutująca się po części ze starej nomenklatury, po części z tzw. nowych Ukraińców - dop. red.] zachowały swoją władzę. Jej gwarancja jest zawiadywanie ogromnymi przedsiębiorstwami regionu" 22 .

Strategię doniecczan dążących do zdobycia wpływu na państwo skomentował Boris Bachtiejew: „Przekształcenie Ukrainy w kolonię Donbasu postrzegane jest przez mieszkańców Donbasu jako dość pożądany stan rzeczy" ${ }^{23}$. W opinii doniecczan dominacja regionu w skali państwa, oznaczająca rozciagnięcie na cały kraj zasad i cnót regionalnych, byłaby korzystna dla całej Ukrainy.

Takie nastawienie odegrało pozytywną rolę w trakcie politycznego kryzysu 2004 r. Podczas listopadowego zjazdu deputowanych północno-wschodnich obwodów Ukrainy w Sewerodonecku (w organizacji którego, nawiasem mówiąc, większą aktywność wykazali posłowie $\mathrm{z}$ regionu charkowskiego) padały postulaty założenia nowego południowo-wschodniego ukraińskiego państwa federalnego ze stolica w Charkowie lub utworzenia autonomii. Ostatecznie zwyciężyła jednak idea kompromisu na poziomie ogólnoukraińskim. Wydaje się, że ważnym rzecznikiem takiego kompromisu były elity donieckie.

\section{Kulturowy wymiar tożsamości}

W literaturze przedmiotu można spotkać dwa przeciwstawne poglądy na temat odrębności kulturowej regionu. W myśl jednego - Donbasu nie da się wydzielać jako samoistnej całości. Np. socjolog Maria Piren w pracy Етнополітика в Украӥні:соціо-психологічний аналіз [Polityka etniczna na Ukrainie: Analiza socjo-psychologiczna], określając regiony historyczno-etnograficzne, włączyła obwody doniecki i ługański do Słobodszczyzny (razem z obwodem charkowskim) ${ }^{24}$.

Przeciwne stanowisko reprezentuje Bachtiejew, który dostrzega istnienie „cywilizacji donieckiej”, nie tylko odrębnej, ale wręcz wrogiej w stosunku do „cywilizacji ukraińskiej”. Pisze on: „Swoja cywilizację mieszkańcy Donbasu postrzegają jako wyższą od ukraińskiej - mimo ilościowej dominacji niewykwalifikowanych górników, mimo zbyt dużej ilości osób z kryminalną przeszłościa, a w związku z tym i z kryminalnym światopoglądem, mimo wyraźnie wiejskiego stylu życia w niecentralnych rejonach dużych miast, nie mówiąc już o górniczych wioskach

${ }^{22}$ Ю. Юров, dz. cyt., s. 191.

${ }^{23}$ Б. Бахтеев, dz. cyt., s. 96.

${ }^{24}$ М. Пірен (M. Piren), Етнополітика в Україні. Соціо-психологічний аналіз [Etnopolityka na Ukrainie. Analiza socjo-psychologiczna], Kyjiv 2007, s. 38, 45. 
[...]. Poczucie wyższości cywilizacji Donbasu wspomagają radzieckie tradycje, a mianowicie typowo radzieckie wyobrażenia o rozwoju ekonomicznym" 25 .

Oczywiście widać tu pewna przesadę, a przy ocenach także nadmierną emocjonalność. Tym bardziej są one uderzające, że cytowany autor dalej sam dziwi się temu (i poddaje ową sytuację krytyce), że na wschodzie Ukrainy „zapadenców” postrzega się jako „bandytów”, a na Zachodzie uważa się za „bandytów” - „wschodniaków”.

Wraz z procesami industrializacji w Rosji kształtowały się charakterystyczne dla tego kraju formy kultury przemysłowej. Tak opisuja ją badacze Uralu: „Kultura hutnicza miała charakter pośredni między tradycyjna kultura ludowa a kultura społeczeństwa przemysłowego. Po ludowej organizacji życia świat przemysłu hutniczego odziedziczył ścisły związek z kalendarzem ludowym, a także z cyklem przyrodniczym i rolniczym. Chłopska kultura cechuje się ponadindywidualnościa, kanonicznością form, które zostały przekazane w prawie niezmienionym kształcie. Miejska kultura przemysłowa jest związana z wyraźnym akcentowaniem indywidualizmu, niezależności oraz prawa jednostki do samorealizacji” ${ }^{26}$.

W dobie industrializacji region doniecki stał się obszarem intensywnej imigracji rosyjskiej, która wywarła wpływ na charakter stosunków etnicznych. W efekcie wielu obserwatorów zewnętrznych zaczęło postrzegać doniecczan jako „Rosjan”, inni zaś, zdający sobie sprawę ze złożoności stosunków etnicznych, określali ich jako „rosyjskojęzycznych”. Gennadij Korżow zwraca jednak uwagę, że także określenie „ludność rosyjskojęzyczna” ma charakter stereotypu: sugeruje ono prorosyjskie i jednocześnie antyukraińskie nastawienie tego środowiska. Tymczasem, zdaniem Korżowa, to właśnie w ramach donieckiego dyskursu tożsamościowego ukształtowały się i tworzyły tak wybitne postacie ukraińskiej kultury jak Vasyl Stus, Iwan Dziuba ${ }^{27}$.

${ }^{25}$ Б. Бахтеєв, dz. cyt., s. 95.

${ }^{26}$ Е.А. Баженова (Е. А. Bażenowa), Механизлы фборлирования уральской идентичности в индустриальную эпоху [Mechanizmy formowania się uralskiej tożsamości w epoce industrialnej], «Известия Уральского государственного университета» [Wiadomości Uralskiego Państwowego Uniwersytetu] 2007, nr 52, s. 261-269.

${ }^{27}$ Г. Коржов, dz. cyt., s. 39, 42. 


\section{Kształtowanie się i ewolucja tożsamości dniepropietrowskiej}

\section{Podstawowa ideologiczna sprzeczność}

„Traumą przy porodzie” Katerynosławia, która ujawnia się w całej jego późniejszej historii, była przepaść między ambitnymi projektami a niezadowalająca rzeczywistościa. Miasto zostało stworzone jako trzecia obok Moskwy i Petersburga - południowa - stolica Imperium Rosyjskiego. Jednak po śmierci ojca założyciela Grygorija Potiomkina Katerynosław przekształcił się w miasto prowincjonalne. Znane osobistości, które odwiedziły miasto, w tym Aleksander Puszkin i Wisarion Beliński, pozostawiły dość negatywne jego opisy, co wszelako nie przeszkodziło mieszkańcom chlubić się tym, że poświęciły miastu swą uwagę. Symbolem sprzeczności w epoce imperialnej był Sobór Przemienienia Pańskiego, zaprojektowany z ogromnym rozmachem, jako budowla w założeniu większa od rzymskiej Bazyliki św. Piotra. Jednak po pięćdziesięciu latach od rozpoczęcia budowy pozostawał nieukończony i ostatecznie jest znacznie mniej okazały od rzymskiego pierwowzoru.

W latach 20., 30. i 40. XX w. Dniepropietrowsk znalazł się w cieniu swoich bardziej dynamicznych sąsiadów - nowo utworzonych okręgów zaporoskiego i krzyworogskiego. Miasto nie miało znacznych rewolucyjnych zasług, jak Charków, nie było stolica radzieckiego górnictwa węglowego, jak Staline, nie miało ogólnoradzieckich budów, jak Zaporoże. Jeśli chodzi o to ostatnie miasto, kierownictwo Komunistycznej Partii Ukrainy rozważało nawet przeniesienie tam stolicy Ukraińskiej Socjalistycznej Republiki Radzieckiej. Komisarz do spraw edukacji Mykoła Skrypnyk mówił: „Teraz prowadzimy budownictwo drugiej w świecie po Niagarze i największej w Europie elektrowni na Dnieprze. Więc tam, gdzie «rwą progi, księżyc wschodzi» - jak mówi Szewczenko - tam, gdzie kiedyś Zaporoska Sicz - tam będzie elektryczne serce Ukrainy [...] będzie nowy ośrodek, nowe centrum Ukrainy, gdzie zapewne w przyszłości będzie stolica Ukrainy ${ }^{28}$.

${ }^{28}$ М. Скрипник (M. Skrypnyk), Чергові завдання соціалістичного будівництва національної політики на Радянській Украӥні [Kolejne zadania socjalistycznego budownictwa narodowej polityki na Radzieckiej Ukrainie], w: tenże, Cmammi ma промови [Artykuły i przemówienia], Харків 1931, t. II, s. 106. Tę samą myśl ów partyjny funkcjonariusz powtórzył i w innym przemówieniu: Національні перетинки [Narodowe Przecięcia], jw., s. 304. Dziękuję Gennadijowi Jefimence z Wydziału Historii lat 20. i 30. XX wieku Instytutu Historii Ukrainy NAN Ukrainy za zwrócenie uwagi na wystapienia Skrypnyka. 
Impulsem, który w czasach radzieckich ożywił ambicje Dniepropietrowska, było stworzenie $\mathrm{w}$ nim wiodacych $\mathrm{w}$ ZSRR przedsiębiorstw przemysłu kosmicznego i rakietowego. Rola „kowala tarczy rakietowej” ojczyzny wzmacniała pozycje miejscowej partyjnej elity w moskiewskich i kijowskich korytarzach władzy, czego symbolem stało się objęcie funkcji generalnego sekretarza Komunistycznej Partii Związku Radzieckiego przez Leonida Breżniewa. W folklorze miasto nosiło nazwę „Ojczyzny zastoju”, a rosyjską historię proponowało się dzielić na okresy: „dopietrowski”, „pietrowski” i „dniepropietrowski”.

Ostatnią jak dotąd nadzieją na realizację wielkich ambicji stało się wybranie na prezydenta Ukrainy Leonida Kuczmy w 1994 r. Oczekiwano, że powstrzyma on załamanie ekonomiczne kraju i regionu, przeprowadzi konieczne reformy rynkowe, a jednocześnie zapewni miastu szczególny status. Jednak nadzieje te okazały się płonne. Reformy wprowadzono tylko częściowo, procesy restrukturyzacji gospodarki ze wszystkimi negatywnymi konsekwencjami trwały jeszcze kolejnych kilka lat. Nawet manifestowana początkowo szczególna życzliwość prezydenta dla miasta $\mathrm{z}$ biegiem czasu wygasła.

\section{Dynamika miejscowych elit}

W odróżnieniu od Doniecka, Katerynosław mimo swego prowincjonalnego statusu może poszczycić się ograniczona, ale jednak ciagła tradycją miejscowej elity. Jako centrum guberni miasto konsolidowało lokalną elitę administracyjna, biznesową i kulturalna, zasilaną także przybyszami z innych regionów. Istnienie silnego ośrodka, którego centrum tworzyła grupa zasiedziałych rodzin szlacheckich i kupieckich, mających własną tradycję lokalna, sprawiało, że rola przybywających z rozkazu władz zwierzchnich notabli i urzędników była stosunkowo ograniczona.

Siła miejscowej elity sprzyjała względnej izolacji od warstw plebejskich. Dotyczyło to nie tylko epoki imperialnej, ale także czasów radzieckich. Z tym, że o ile przed $1917 \mathrm{r}$. podstawę wyodrębnienia elity stanowiło pochodzenie, po rewolucji stanowił ja poziom oświaty i kultury. Jak zaznaczali niektórzy respondenci, w latach 70 . rzucał się w oczy drastyczny dystans między kierownictwem a pracownikami przedsiębiorstw Dniepropietrowska, dość dziwny dla ludzi z Zagłębia Donieckiego, przyzwyczajonych do partnerskich stosunków w miejscu pracy.

Jeszcze jedna cechą dniepropietrowskich elit jest wysoki poziom wewnętrznej rywalizacji (dotychczas nie udało się ustalić, czy istniała ona również w epoce imperialnej). Jedną z przyczyn tego zjawiska może 
być duża różnorodność gospodarcza regionu - obok tradycyjnych branż, takich jak górnictwo i hutnictwo, rozwijały się też dziedziny nowoczesne, zwiazane z przemysłem rakietowym i kosmicznym. Otwierało to pole do porównań i rywalizacji. Stało się to szczególnie widoczne po $1991 \mathrm{r}$.

W połowie lat 90. Dniepropietrowsk stał się areną politycznego współzawodnictwa prezydenta Ukrainy Leonida Kuczmy i premiera kraju Pawło Łazarenki (którego wsparła w pewnym momencie Julia Tymoszenko). Równolegle doszło do konfrontacji kilku potężnych grup finansowo-przemysłowych, należących do przedstawicieli elity regionu, w tym: Intertape, Privat oraz struktur należących do Tymoszenko i Łazarenki.

Obwód dniepropietrowski miał wreszcie „własny Donbas” - miasto Krzywy Róg. Centrum przemysłu hutniczego i górniczego, którego struktura społeczno-gospodarcza, a nawet pejzaż (nie tylko hałdy, lecz także gigantyczne wyrobiska rudy żelaznej) przypominają Donieck. Zdarzało się, że miejscowe elity próbowały uciec od dominacji Dniepropietrowska. Dwukrotnie podjęto starania na rzecz utworzenia obwodu krzyworoskiego. Jednak w obu przypadkach notablom z Dniepropietrowska udawało się powstrzymać te działania, przede wszystkim dzięki awansowaniu krzyworoskich funkcjonariuszy partyjnych do władz Dniepropietrowska. Zreszta obecnie w osłabionym kadrowo i ekonomicznie Dniepropetrowsku pierwsze skrzypce grają ludzie pochodzący właśnie z Krzywego Rogu.

\section{Przestrzenny wymiar tożsamości}

Dominujący element dniepropietrowskiej tożsamości przestrzennej stanowi rzeka Dniepr. I w języku potocznym często nazywa się miasto po prostu: „Dniepr” - mówią tak zarówno mieszkańcy miasta, jak i ludzie pochodzący z innych regionów. Właśnie z tą rzeką można powiązać stosunkowo dużą rolę „ukraińskiego ludowego elementu” w miejscowej tożsamości. Tak samo rzeka „ukrainizuje” (oraz jeszcze jeden narodowy symbol: wyspa Chortyca) także sasiednie rosyjskojęzyczne miasto, Zaporoże. Do 1928 r. Dniepropietrowsk miał jeszcze jeden „ukrainizujący” czynnik - niedaleko od południowych okolic miasta zaczynały się progi [porohy - red. RDSG] Dniepru, odgrywające niezwykle istotna rolę w historii Kozaczyzny, zatopione w wyniku spiętrzenia rzeki przez tamę Dnieprogesu.

Wielka rzeka i progi na Dnieprze prawdopodobnie spowolniły tempo industrializacji Katerynosławia. Dopiero budowa mostu i linii kolejowej łączącej donieckie zagłębie węglowe i kopalnie rud żelaza w Krzywym Rogu pozwoliły na przyspieszenie tempa rozwoju przemysłu. 
Tak tę sytuację opisywał Boris Tichonow: „Wyznaczając miejsca dla nowych zakładów, kapitaliści musieli wybierać pomiędzy ich bliskościa do krzyworoskiej rudy lub do donieckiego węgla. Lecz po otwarciu jekaterynosławskich kolei pierwsze przedsiębiorstwa powstały na Dnieprze, koło Katerynosławia, właśnie «między» rudą i węglem [...]. W rejon Katerynosławia należało dowozić i rudę żelaza, i węgiel, tyle że nie na całą odległość między Krzywym Rogiem i Donbasem, ale tylko na jej część. Oprócz tego zakłady Naddnieprza znajdowały się stosunkowo blisko od Nikopolskiego złoża manganów [...]. Warto wspomnieć i to, że Katerynosław był położony w centrum dużego, dobrze rozwiniętego regionu rolno-spożywczego, który mógł łatwo zabezpieczyć zapotrzebowanie ludności miejskiej i handlowo-przemysłowej na artykuły żywnościowe" ${ }^{29}$.

Zatem połączenie przeciwieństw, koordynacja różnych wektorów rozwoju, „budowa mostów” stały się naturalną funkcją miasta w południowej Rosji. Stąd most - a dokładniej: mosty przez Dniepr - są drugim co do ważności krajobrazowym elementem miejscowej tożsamości.

\section{Wymiar społeczno-ekonomiczny tożsamości}

Do połowy XIX w. Katerynosław był w przeważającej części miastem rolniczym - ze świniami i kurami, które wypasały się w centrum, $\mathrm{z}$ chatami lepiankami. Pod koniec XIX w. miasto stało się centrum hutnictwa i budowy maszyn Imperium, od 1863 do 1897 r. ludność zwiększyła się prawie dziesięciokrotnie ${ }^{30}$. W obrazie miasta nastapiły wtedy istotne zmiany: staje się szlacheckie i kupieckie, z zadbanym centrum i kamienicami.

W okresie 1921-1950 region dniepropietrowski był obwodem przede wszystkim proletariackim i hutniczym. W latach 50. i 60. miasto przekształcono w ośrodek pracujący na potrzeby radzieckich wojsk rakietowych i ze względu na wymogi utrzymania tajemnicy wojskowej oraz bezpieczeństwa izolowano. Było m.in. zamknięte dla obcokrajowców, do tego stopnia, że miejscowa drużyna piłkarska, uczestnicząc w rozgrywkach międzynarodowych, podejmowała swych przeciwników w Krzywym Rogu. Natomiast od końca lat 80. Dniepropietrowsk otwarcie promuje się jako centrum przemysłu rakietowego i kosmicznego.

${ }^{29}$ Б. Тихонов (В. Тichonow), Каменноугольная промышленность и черная металлургия России во второй половине XIX в. [Przemysł węglowy i hutnictwo Rosji w drugiej połowie XIX w.], Москва 1988, s. 148-149.

${ }^{30}$ I. Гуржій, dz. cyt., s. 9. 


\section{Tożsamość polityczna i stosunek do Ukrainy}

Elity regionu miały tradycyjnie duże ambicje polityczne. Przy czym nie chodziło o dążenie do samodzielnego kształtowania polityki państwa, ale raczej do zajmowania ważnego miejsca $\mathrm{w}$ realizacji strategii wypracowywanej $\mathrm{w}$ stolicy. Stąd też nastawienie na współpracę z Petersburgiem w okresie imperialnym, a później orientacja na Moskwę, decydujaca w kwestiach tworzenia i rozwoju centrum rakietowego. W tym czasie Kijów był tu postrzegany ambiwalentnie - jako konkurent w walce o uwagę Moskwy, ale też jako sytuacyjny sojusznik w grach w korytarzach władzy.

Elity dniepropietrowskie, dążące do utrzymania znaczącej pozycji w ramach państwa, pozytywnie ustosunkowywały się do niepodległości Ukrainy, pragmatycznie spodziewając się podwyższenia swego statusu, chociaż znaczna część jego przemysłowego i intelektualnego potencjału nie była potrzebna nowemu krajowi, pozbawionemu imperialnych i wojowniczych ambicji. W pierwszym dziesięcioleciu niezależności często podkreślano, że miasto nie jest pierwszorzędne, ale i nie drugorzędne na Ukrainie.

Jednak migracja elit do Kijowa oraz brak nowego, ambitnego zadania osłabiły dniepropietrowską tożsamość regionalną. Jej dominantą stała się nieufność do polityków wywodzących się z miejscowego środowiska. Leonid Kuczma podczas swoich pierwszych prezydenckich wyborów w 1994 r. otrzymał w regionie 68,81\% głosów, ale pięć lat później już zaledwie 56,38\% (a trzeba pamiętać o rozmaitych działaniach administracyjnych, które znacznie poprawiły wynik tego kandydata), podczas gdy jego przeciwnik, komunista Petra Symonenko - 38,08\%. W pierwszej turze ostatnich wyborów prezydenckich w obwodzie Dniepropietrowskim „miejscowi” Sergij Tihipko i Julia Tymoszenko otrzymali łącznie 37,26 \% głosów, natomiast „doniecki” Wiktor Janukowicz - 41,67\%. W drugiej turze głosy Tihipko zostały podzielone prawie na pół pomiędzy Tymoszenko a Janukowicza $(29,13 \%-62,7 \%)^{31}$.

Jak wypowiadał się jeden z respondentów, którego raczej można zaliczyć do przedstawicieli miejscowej intelektualnej elity - trzeba głosować na mieszkańców Dniepropietrowska, bez względu na ich ideologiczne i partyjne kolory, bo przecież właśnie to będzie gwarancją rozkwitu miasta; rzecz jasna większość mieszkańców przyjęła inny punkt widzenia. W trakcie prezydenckiej kampanii wyborczej autor osobiście obserwował fenomen, gdy „dniepropietrowska” tożsamość przejawiała

${ }^{31}$ Dane Centralnej Komisji Wyborczej Ukrainy - http://www.cvk.gov.ua/pls/vp2010/ WP0011. 
się częściej u mieszkańców innych regionów niż u obywateli miejscowych, którzy zajęli pozycje wyczekujące.

Dzisiaj w obwodzie dniepropietrowskim jest widoczny proces politycznego „utożsamienia z Donbasem”, co nie wywołuje szczególnego oporu - uczestnictwo w realizacji ambitnych celów w ramach donieckiej tożsamości nie jest gorszym wariantem niż dalszy dryf.

\section{Kulturowy wymiar tożsamości}

Jak i wiele innych miast na południu Rosji, katerynosławska tożsamość formowała się na podstawie dwóch dyskursów - ukraińskiego, kozackiego i wiejskiego oraz rosyjskojęzycznego, imperialnego (przy czym ostatni był ponadnarodowy, a nie rosyjski). Zreszta ukraiński dyskurs był obecny stale, niekiedy dość niespodziewanie wypływając na powierzchnię. W dniepropietrowskim muzeum historycznym można usłyszeć anegdotę, jak podczas wizyty imperatora Mikołaja II w 1915 r. pierwszy dyrektor muzeum Dmytro Jawornycki oprowadzał wycieczkę, używając języka ukraińskiego. Na uwagę, dlaczego nie mówi po rosyjsku, powiedział: „Niech car zna nasz język!”32

Podczas wojny Katerynosław był jednym z najbardziej ukraińskich proletariackich miast. W tym kontekście warto również przytoczyć słowa jednego z respondentów Portnowa, który nazwał Dniepropietrowsk „największym ukraińskim miastem”33, aczkolwiek sam Portnow interpretował tę tezę jako komentarz do „dniepropietrowskiego modelu - otwartości na wszystko i jednocześnie niezdolności do zbudowania czegoś trwałego". Zapewne, można widzieć tu dowód na to, że ukraiński dyskurs pozostaje jedna z bazowych światopoglądowych podstaw miejscowej tożsamości, która pozostaje niezależna od wymogów politycznych. Co ciekawe w tym kontekście: za czasów radzieckich herb miasta był hutniczy (il. 2), później zmienił się na kozacki i analogicznie zostało opracowane godło obwodu. Jednak logo obwodu, przyjęte w 2010 r., połączyło w sobie tak kozacki, jak i wielonarodowy rakietowo-hutniczy aspekt terytorialnej tożsamości (il. 3).

${ }^{32}$ М. Скиданова (M. Skydanowa), История Днепра: как возводили град Екатерины [Historia Dniepru: jak budowano gród Katarzyny], «Сегодня» [Dziś] z 26 XI 2011.

${ }^{33}$ П. Солодько, dz. cyt. 

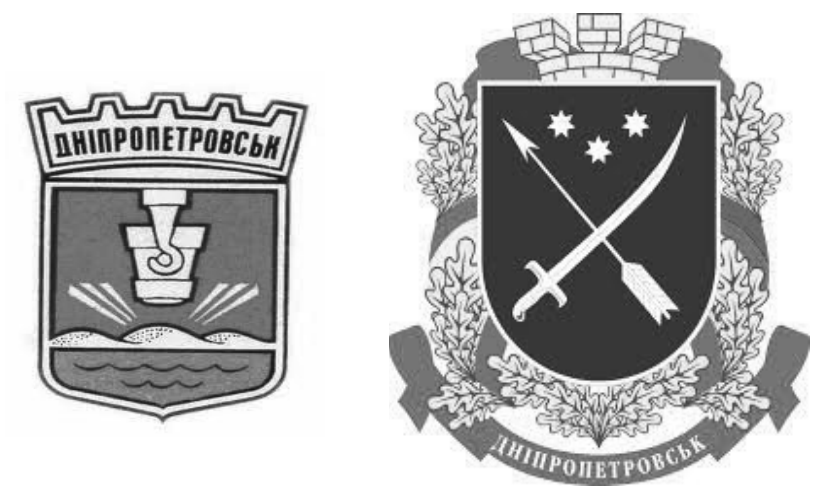

Il. 2. Herby Dniepropietrowska: z okresu radzieckiego oraz herb współczesny
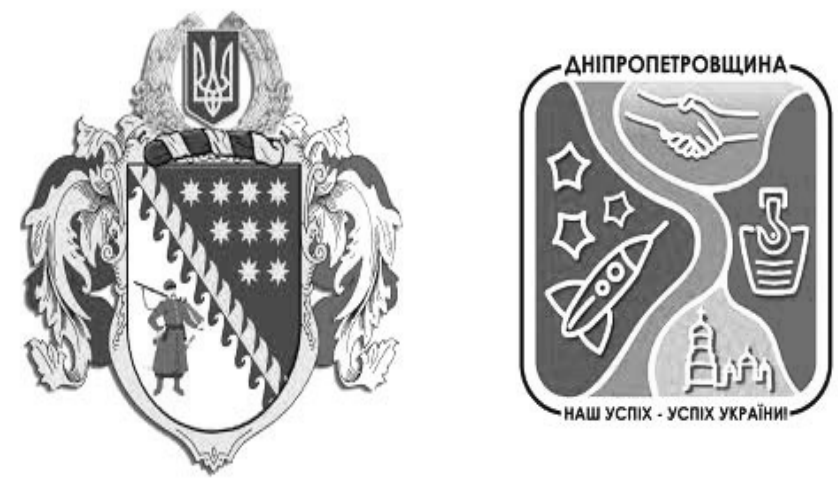

Il. 3. Współczesne godło i logo obwodu dniepropietrowskiego

Lata 90. w regionie dniepropietrowskim minęły pod znakiem poszukiwania nowego miejsca w nowym państwie. W pierwszej dekadzie XXI w. zaobserwować można było znaczne wychylenie ku dyskursom narodowym - kozackiemu i ukraińskiemu, odzwierciedlonym w „bardziej kozackim” godle miasta i obwodu. Kolejna dekada przyniosła przesunięcie oficjalnej historii miasta $\mathrm{w}$ kierunku sowietyzacji, wyrazem czego stało się założenie placu imienia 80-lecia Obwodu Dniepropetrowskiego (obok państwowej administracji obwodowej i rady obwodowej), gdzie rozmieszczono tablice ze spiżowymi płaskorzeźbami przedstawiajacymi wybitnych działaczy i najważniejsze historyczne wydarzenia regionu (oczywiście - według dzisiejszych kierowników obwodu i miasta). Analiza dniepropietrowskiego panteonu osób i wydarzeń pokazuje, że główne miejsce zajmuje dyskurs radziecki. Do kozackiego dyskursu należą Iwan Sirko, Dmytro Jawornycki i Bohdan Chmielnicki, który w 1648 r. otrzymał hetmańską buławę 
w miejscowości Mykytyńska Sicz, obok dzisiejszego Nikopola (miasto Obwodu Dniepropetrowkiego). Do dyskursu imperialistycznego zaliczymy cztery postacie: namiestnika regionu katerynosławskiego Iwana Sinielnikowa, gubernatora guberni katerynosławskiej Andreja Fabra, przedsiębiorcę Oleksandra Pola, politycznego działacza Myhajła Rodziankę. Jednego - byłego prezydenta Kuczmę - można odnieść do współczesności. Natomiast 8 z 15 osób to przedstawiciele epoki radzieckiej: wojskowi, przemysłowcy, górnicy, pisarz Ołeś Honczar oraz dwóch sowieckich przywódców - Leonid Breżniew i Wołodymyr Szczerbycki. Ciekawe, że do tego grona nie dostali się założyciel Katerynosławia Grygorij Potiomkin i działacz rewolucyjny Georgij Pietrowski, którego imię teraz nosi miasto.

Godne uwagi jest nie tylko nawiązanie nazwy placu do radzieckiego okresu, lecz także jego geograficzne położenie pomiędzy ulicami Komsomolską i Szczerbyckiego. Nawiasem mówiąc, pierwsza z nich nazywała się tak i w radzieckim okresie, a druga do 2003 r. była ul. Nowa, co było „kompromisem” zawartym z siłami narodowo-patriotycznymi - jednocześnie ul. Kirowa zmieniła nazwę na Ołesia Honczara. Tak więc oficjalna dniepropietrowska tożsamość w znacznej mierze utknęła w radzieckiej przeszłości. I chociaż jeszcze za wcześnie oceniać, w jakim stopniu zostanie ona przyjęta przez mieszkańców, całkiem prawdopodobny jest odbiór pozytywny.

\section{Wzajemne oddziaływania i podobieństwa tożsamości donieckiej i dniepropietrowskiej}

W całym opisywanym okresie regiony Dniepropietrowska i Donbasu konkurują ze soba. W epoce uprzemysłowienia rywalizacja między regionami dotyczyła dostępu do szlaków komunikacyjnych i surowców (np. węgla dla hut), w okresie radzieckim walczono o uzyskanie państwowych funduszy inwestycyjnych, wykwalifikowanych kadr, uzyskanie wpływu na partyjnych przywódców w Moskwie, w okresie niezależności wreszcie - o kontrolę nad przedsiębiorstwami i ich finansami oraz zdobycie przez lokalne elity wpływu na centralne organy władzy państwowej.

Apogeum rywalizacji elit obu regionów miało miejsce w połowie lat 90. - gdy „dniepropietrowskie” grupy wpływu zdominowały aparat państwowy Ukrainy. Jednak już po kilku latach, w przeddzień prezydenckich wyborów 1999 r., doszło do kompromisu w postaci umowy o współpracy obwodów dniepropietrowskiego i donieckiego, podpisanej w obecności prezydenta Kuczmy. Porozumienie to zapewniło Kuczmie 
wybór na drugą kadencję, a donieckim elitom biznesowym możliwość ekspansji ekonomicznej poza granice swojego regionu.

Dobrą ilustrację różnic między analizowanymi tożsamościami regionalnymi daje porównanie dwóch symbolicznych postaci: górnika uosabiającego etos Donbasu z dniepropietrowskim inżynierem-pracownikiem przemysłu rakietowego. Górnik był i jest postrzegany w Donbasie jako wzór „prawdziwego mężczyzny”. Reprezentuje siłę, odwagę, zdolność do wytężonej systematycznej pracy, solidarność z innymi członkami świata górniczego, oddanie dla rodziny. Ale już w Dniepropietrowsku widzi się w nim tylko osobę wykonująca ciężka, a i niewymagająca zbytnich kwalifikacji pracę. Inżynier natomiast, postrzegany w Dniepropietrowsku jako specjalista o wysokich kompetencjach, zdolny do wykonywania skomplikowanych zadań, a przy tym człowiek dużej kultury osobistej - z perspektywy Doniecka to raczej urzędnik, nieznający i nierozumiejący prawdziwej pracy, niezdolny do tego, by poradzić sobie w prawdziwie trudnych warunkach.

Wskutek kryzysu społeczno-gospodarczego lat 90. donieckie kopalnie niszczeja, natomiast hutnictwo przeżywa etap uniesienia. $\mathrm{W}$ regionie dniepropietrowskim technologiczne branże dotyka regres, lecz hutnictwo i sektor górniczy dalej istotnie zwiększają swoją wagę w produkcji przemysłowej. Tym samym ekonomiczna baza regionów wyrównuje się, co tworzy podstawy dla mentalnego zbliżenia. Jednocześnie widoczne sa i inne tendencje w zakresie regionalnej specjalizacji gospodarczej. $\mathrm{Na}$ przykład w Dniepropietrowsku dużą wagę mają sektory bankowy i telekomunikacyjny - chociaż jeszcze za wcześnie mówić o sile ich wpływu na samoidentyfikację ludności regionu.

Porównując preferencje polityczne, można zobaczyć, że doniecka tożsamość bardziej przypomina radziecka - właśnie tu prawie 10 lat po odzyskaniu niepodległości dominowały komunistyczne nastroje. Dniepropietrowsk w tym obszarze wykazał większą ideologiczną różnorodność. W latach 90 . w obu obwodach można zaobserwować wzmocnienie regionalnej tożsamości, socjolodzy tłumaczą to w następujący sposób: „Regionalna tożsamość na Południu i Wschodzie odgrywa rolę kompensacyjna, dla wielu mieszkańców wypełniając miejsce po utraconej starej, gdy nienabyta jest jeszcze nowa tożsamość państwowa" ${ }^{34}$. Jednak dwa kryzysy - polityczny 2004 r. oraz gospodarczy z lat 2008-2009 unaoczniły, że bez względu na problemy polityczne Ukraina wysuwa się tu coraz bardziej na pierwsze miejsce.

Jeśli chodzi o narodowo-kulturalną orientację mieszkańców obu regionów, jaka wyłoniła się po pierwszym etapie industrializacji,

${ }^{34}$ Г. Коржов, dz. cyt., s. 40. 
znamienna jest uwaga z 1920 r. wspomnianego już komisarza ds. edukacji Skrypnyka - o zaistnieniu potrzeby „pogodzenia ze sobą regionu naddnieprzańskiego i jego ukraińskich pracowników o drobnomieszczańskich i narodowych odcieniach poglądów - z rosyjskim Donbasem" ${ }^{35}$.

Mimo że region katerynosławski (w granicach obecnego obwodu dniepropietrowskiego) rzadko był postrzegany w tym okresie jako część regionu doniecko-krzyworoskiego, to jednak - będąc pograniczem między proletariackimi centrami Donbasu i chłopskim rejonem naddnieprzańskim - demonstrował w kwestii narodowej tendencje „naddnieprzańskie”, zwłaszcza ze względu na dużą cząstkę wiejskiej ludności regionu. W latach 20. i 30. XX w. Donbas stawał się coraz mniej rosyjski - dawała o sobie znać kampania ukrainizacji. Region dniepropietrowski, z większą przewaga ludności wiejskiej i bez dużych socjalistycznych budów, również wzmacniał swój element ukraiński. Można tu przypomnieć, że w okresie nieurodzaju i głodu w latach 1928-1929 okręg dniepropietrowski wykazywał, według danych Państwowego Zarządu Politycznego (ODPU), taki sam negatywny stosunek do Moskwy (np. oczekiwania, „kiedy zacznie się wojna z Rosja”), jak inne, rolnicze, części Ukrainy ${ }^{36}$.

Po wojnie w Donbasie umacniała się właśnie tożsamość regionalna, ale też stopniowo, w sposób naturalny, obwód się ukrainizował. Dniepropietrowsk natomiast coraz bardziej stawał się centrum miejskiej kultury rosyjskiej w Ukrainie południowej, jednak również w sposób naturalny, bez przymusowej rusyfikacji. Po 1991 r. region ten, choć nie zmienił wektora na ukraiński, znacznie spokojniej niż Donieck patrzył na nowe kulturalne inicjatywy z Kijowa.

Rozważając obecny stan obu przedstawionych tożsamości terytorialnych, warto dostrzec inicjatywy przedstawicieli elit intelektualnych badania systemu wartości w różnych regionach kraju. Np. we Lwowie działa tzw. Uniwska Grupa, podobne formacje sa i w innych miastach. Występując w ramach projektu publicznych wykładów TEDx Talks, medioznawca Ewgen Glibowicki i historyk Jarosław Hrycak prezentowali wstępne wyniki warsztatów ${ }^{37}$ : okazuje się, że za główną wartość Lwowa

${ }^{35}$ М. Скрипник, Донбас та Україна [Donbas a Ukraina], w: М. Скрипник, Cтатті та промови з національного питання [Artykuły i przemówienia w sprawie narodowej], Мюнхен 1974, s. 17.

${ }^{36}$ Rękopis: Л. Гриневич (L. Grynewicz, starszy pracownik naukowy Wydziału Historii Lat 20. і 30. XX w. Instytutu Historii Ukrainy NAN Ukrainy), «Влада і українське суспільство в умовах недороду і голоду 1928/29 p.» [Władza i ukraińskie społeczeństwo w warunkach nieurodzaju i głodu w latach 1928-1929]. Dziękuję autorowi za możliwość zapoznania się z tą praca.

${ }^{37}$ Я. Грицак (J. Hrycak), Є. Глібовицький (E. Glibowicki), «Цінності України» [Wartości Ukrainy], referat na TEDx Talk, 18 VI 2011. 
uznano „jakość życia”, Odessy - „szybkość w podejmowaniu decyzji”, jeśli zaś chodzi o przedstawione tu miasta: w przypadku Dniepropietrowska - „ambicję, przezorność”, a Doniecka - „działania”. Harmonijne połaczenie tych wszystkich wartości mocno wspomagałoby dalszy rozwój kraju; pytanie tylko: jak osiagnaćc tę pożądaną harmonię?

$$
* \quad * \quad *
$$

Tożsamości terytorialne mieszkańców Doniecka i Dniepropetrowska stanowią warianty tzw. ukraińskiej tożsamości postsowieckiej, neutralnie, a w niektórych wypadkach negatywnie zorientowanej wobec państwa ukraińskiego. Wydaje się jednak, że gdy przestrzeń polityczna i gospodarcza całej Ukrainy znalazła się pod dominujaccym wpływem elit reprezentujących te właśnie tożsamości, powstały warunki do wzmocnienia tendencji identyfikacji środowisk postsowieckich z państwem ukraińskim.

Bez wątpienia oczekiwane zmiany nie będą miały charakteru radykalnego ani nie będą następowały szybko. Prawdopodobnie będą polegały na powolnym wzmacnianiu poczucia więzi z państwem ukraińskim jako państwem pozwalającym realizować własne interesy ekonomiczne i polityczne. Równocześnie ekspansja w ukraińskiej przestrzeni publicznej regionalnych tożsamości donieckiej i dniepropietrowskiej pozytywnie wpłynie na formowanie terytorialnych samoidentyfikacji innych regionów kraju, a tym samym przyczyni się do ożywienia i pogłębienia ogólnoukraińskiego dyskursu tożsamościowego.

Wołodymyr Hołowko

The local identity of industrial regions of Ukraine: Donetsk and Dnepropetrovsk. An Outline

(Summary)

The article studies the coming into existence and development of regional identities in the two most industrialized regions of Ukraine: Donbas and Dnepropetrovsk. Territorial identity is analyzed using the following criteria: basic conflicts regarding outlook, the establishment and development of regional elites, political, ethnic, cultural and socio-economic factors, attitude to the centre of the state. Identities are discussed as the key components of the postmodernistic ideology of the Ukrainian political elite.

Key words: social (regional) identity, Ukraine, Donetsk, Dnepropetrovsk 